\title{
AIDS advocates and doctors brace for impact of lost funding
}

\author{
"Now is not the time to falter," UN Secretary- \\ General Ban Ki-moon announced at a UN \\ General Assembly meeting on 16 June. He \\ was referring to global commitments in the \\ fight against HIV, which he worries might be \\ suffering as a result of the current economic \\ situation. The crisis "should not be an excuse \\ to abandon commitments - it should be an \\ impetus to make the right investments that \\ will yield benefits for generations to come," \\ he said.
}

On first glance, HIV funding seems to be higher than ever. In March, Congress announced it was providing The Global Fund to Fight AIDS, Tuberculosis and Malaria-a Washington, DC-based publicprivate partnership - with $\$ 900$ million this year, a $\$ 61$ million increase over 2008. And a Kaiser Family Foundation and UNAIDS report published in July 2009 reported that between 2002 and 2008, HIV-related commitments and disbursements from

\section{HIV gender clues emerge}

Women with untreated HIV tend to develop AIDS faster than HIV-infected men. Now, a new study provides insights as to why: women infected with the virus produce more immune-stimulating protein than infected men do.

Marcus Altfeld, an immunologist at Harvard University in Cambridge, Massachusetts, and his colleagues examined the role that the so-called 'plasmacytoid dendritic' cells of the immune system have in ramping up the body's defenses against HIV. These cells have a receptor-called Toll-like recptor-7 (TLR7) - that allows them to recognize single-stranded RNA, such as that found in the HIV virus. They are one of "the initial sensors of an infection," Altfeld explains.

In the laboratory, Altfeld and his colleagues exposed cells from uninfected men and women to HIV. The women's dendritic cells produced significantly more interferon-alpha, an immunestimulating protein. "It was a very specific gender difference," Altfeld says. Additional laboratory experiments revealed that the higher interferon-alpha production in women led to increased activation of $\mathrm{CD}^{+} \mathrm{T}$ cells, immune cells that bind infected cells and destroy them. That's important, Altfeld says, because " $\mathrm{CD} 8^{+} \mathrm{T}$ cell activation is one of the strongest predictors of [HIV] disease progression."

To test their results, Altfeld and his colleagues took blood samples from 109 HIV-infected women and 514 HIVinfected men who had not yet received treatment. As they report in this issue of Nature Medicine, women had $4.6 \%$ more activated $\mathrm{CD} 8^{+}$cells than men with the same amount of virus (Nat. Med. 15, 955-959; 2009).

Altfeld and his colleagues suspect that the sex hormone progesterone may be responsible for the differences. In premenopausal women, Altfeld and his colleagues observed a correlation between higher progesterone levels at certain points in the menstrual cycle and increased immune activation.

Pediatric specialists, meanwhile, remain uncertain as to whether the same difference in HIV response is present in younger patients, since young girls produce only a fraction of the amount of progesterone that adult women do: While young, HIV-positive girls seem to have a higher mortality rate than their male counterparts, "it's not clear to me that the mechanism [behind this gender difference] would be the same" as that seen in adults, says Marc Foca, director of the Pediatric HIV Clinic at the New York-Presbyterian Morgan Stanley Children's Hospital.

Altfeld says that the results, taken together with previous findings, also suggest a new drug target: the TLR7 receptor. In fact, Altfeld says that biotech companies are already developing drugs designed to block TLR7 signaling to treat autoimmune diseases, which disproportionately affect women. "If these drugs prove to be safe, we could test them in chronically HIV-infected individuals and see whether we can reduce immune activation," he says. "It might be an alternative approach for treatment of HIV."

Cassandra Willyard, New York developed nations increased by more than fivefold.

But the authors also admit that their figures reflect budgets "largely set in place before the acceleration of the current global economic crisis." The US, in particular California, already seems to be struggling to maintain commitments: a joint legislative committee in California voted to slash $\$ 33.5$ million from the state's HIV/AIDS education, prevention and treatment programs in June. In addition, a report released in July by the HIV Vaccine and Microbicide Resource Tracking Working Group, composed of various organizations, including UNAIDS, found that investments in AIDS vaccine research declined this year for the first time since 2000 .

"When you have an increased demand from the field, and your resources are constrained, there's absolutely no doubt that there's going to be an impact," says Natasha Bilimoria, president of Friends of the Global Fight Against AIDS, Tuberculosis and Malaria, a Washington, DC-based advocacy organization that attracts support for the Global Fund.

A separate joint UNAIDS-World Bank report published in June surveyed UNAIDS, World Health Organization and World Bank staff from 71 countries in March 2008 and found that $11 \%$ of the aid workers were already experiencing cutbacks in their antiretroviral treatment programs, whereas $31 \%$ expected problems in the coming year.

The current economic situation could be affecting the HIV/AIDS epidemic in more direct ways as well. Lower incomes may prevent some individuals from paying for their antiretroviral treatments or traveling to get them. Others may not be able to maintain the healthy diet necessary for the drugs to work properly. "The vast majority of people we are trying to reach are already desperately poor," says Wafaa El-Sadr, director of the International Center for AIDS Care and Treatment Programs at Columbia University's Mailman School of Public Health. “They're in a very tenuous situation.”

El-Sadr says it is especially sad to see these problems arising now. "People a few years ago doubted that you could scale up HIV programs in Africa. Now we've proven that it can be done," she says. "This break in momentum is really dismaying." To keep the glimmer of hope alive, she says, clinics and organizations will simply have to "do a lot more with what we have."

Melinda Wenner, New York 